\title{
Learner-Centered Instruction in Pre-Service Teacher Education: Does it Make a Real Difference in Learners' Language Performance?
}

\author{
Salma Al-Humaidi ${ }^{1, *}$, Thuwayba A. Al Barwani ${ }^{1}$ \& Abdo Al Mekhlafi ${ }^{1}$ \\ ${ }^{1}$ College of Education, Sultan Qaboos University, PO Box 32 PC 123 Al Khoud, Sultanate of \\ Oman \\ *Corresponding author: College of Education, Sultan Qaboos University, PO Box 32 PC 123 \\ Al Khoud, Sultanate of Oman. Tel: 968-2414-3976 E-mail: shumaidi@squ.edu.om
}

Received: May 14, 2014 Accepted: September 16, 2014 Published: December 9, 2014

doi:10.5296/ije.v6i4.6752ＵRL: http://dx.doi.org/10.5296/ije.v6i4.6752

\begin{abstract}
The current study investigated the effect of implementing learner centered methodologies in a teacher education program. More specifically, it looked at the impact of exposing prospective teachers to learner centered methodologies through an EFL methods course. In turn, the effects of this approach on their school students' performance in English language skills (reading, writing, and speaking) were examined. The study used a quasi-experimental design where the performance of a group of school students using learner centered methodology (experimental group) was compared to the performance of another group of school students using non- learner centered approaches (control group). The study further examined whether significant differences existed between the performance of the two groups that can be attributed to gender and the school environment. Moreover, the study looked into students' attitudes towards language in a learner-centered environment. The instruments used in this study are the National test designed by the Ministry of Education and an attitude questionnaire that was adapted from the learner-centered methodology program document of the Ministry of Education. Major findings reveal significant differences in the performance of students in the two types of schools in favor of learner-centered schools. Despite the differences between the two groups on all measures, students' language performance of both learner centered and non-learner centered schools was found to be lower than the Ministry of Education specified minimum score.
\end{abstract}

Keywords: Learner-centered, Pre-service, Teacher education, Language performance 


\section{Introduction}

Teaching and learning methods, approaches and techniques are constantly evolving to meet the changing needs of teachers and students alike. Thirst for improvement and attempts to keep pace with any new developments in the discipline have created a healthy competition among area specialists who constantly strive to avoid the dreaded sobriquet of traditionalist. This has resulted in a number of attempts to try out and implement a plethora of new methods and techniques with widely varying degrees of success. A good many of these attempts have fallen short of their terminal goals. Some educators who try to adopt new pedagogical approaches because they are current or fashionable and are often unable to voice their concerns due to their lack of expertise in applying these new ideas. This can and does sometimes lead to their being labeled backwards or less-than-proficient in their fields even by those who only claim to know it all. Moreover, even when these new trends are applicable and sound in nature, it is still questionable how much they contribute in any practical manner to student improvement. This is especially true if, at the end of the day, such newfangled approaches are sought after and applied for the sake of appearances and/or for the bolstering of one's reputation as a cutting-edge educator. Unfortunately, the field of English language teaching is not immune to this condition.

\section{Theoretical Framework}

In response to the need for school improvement, the ongoing research in education is focusing on exploring various approaches, methods, and techniques based on sound theoretical grounds. These methods of instruction, for the most part, cluster around either teacher-led or learner-centered (or student-centered) approaches. Learner-centered approaches in ELT take a number of forms though they are fundamentally similar in nature. They all stem from the notion of 'learning by doing' rather than being led by the teacher. The most prominent of these are active learning and service learning approaches. In the literature on teaching and learning, the term 'student-centered learning' is widely used (Young, 2000:72). Other terms used in the literature linked to this are 'experiential learning' (Burnard, 1999), 'flexible learning' (Taylor, 2000), and 'self-directed learning' (O'Neill and McMahon, 2005:27).

The concept of 'student-centered learning' is credited to Hayward in the beginning of the last century and to Dewey in the 1950s (O'Sullivan, 2003). Rogers (1983) expanded the concept of 'client-centered counseling' into a general theory of education to refer to a shift in power from the 'expert' teacher in a teacher-centered environment (where students are passive, apathetic and bored) to the student 'learner'. The idea is also linked to the work of Piaget and more recently with that of Malcolm Knowles (Burnard, 1999). Another related concept is that of 'child-centered education', which is derived from the work of Froebel (Simon, 1999).

A 'strand' emerged in the seventies with a focus on the learner "under the rubric of individualized instruction and more generally, individualization." This includes self-access learning, self-directed learning, and the movement towards learner autonomy, all of which 
"focus on the learner as an individual and seek to encourage learner initiative and to respect learner differences." Individualization was replaced in the 1980 s by the term learner-centeredness, which refers to the belief that attention to the nature of learners should be central to all aspects of language teaching, including planning, teaching, and evaluation" (Richards 2002, p. 15).

There does not seem to be a single theoretical basis for student-centered learning in the literature. It appears to relate primarily to the 'constructivist' view and the importance it places on activity, discovery and independent learning (Carlile and Jordan, 2005). While the cognitive theory emphasizes 'activity' in the learner's head (or the mind), the constructivist view emphasizes activities, such as projects and practicums in which students are required to engage themselves in some form of physical activity. The 'social-constructivist' view of learning also emphasizes activity and the importance of communities of practice in the learning process.

Research has empirically shown evidence for and against the use of learner centered approaches. Some studies such as Geisli, 2009; Ahmed and Mahmood, 2010; and Atara et al., 2000 show positive effects of student centered training approaches on students' achievements and the quality of learning. At the same time, other studies indicate there are complex factors such as learner and teacher characteristics that call into question the quick and simple implementation of these approaches and the concomitant positive effects of the same.

Geisli (2009) conducted a study to determine the effect of student centered training approaches on student success. A pre-/post-test experimental design was used with a control group and an experimental group. The tool for data collection was an achievement test developed by the researcher. The results showed that measured success was significantly higher in the group where student centered methods were applied compared to the teacher centered group.

Another study that showed a significant difference in students' achievement is that of Ahmed and Mahmood in (2010). They investigated the effects of three experimental learning conditions on prospective teachers' learning experience and achievement in an educational psychology course. These conditions include a traditional instruction model and two cooperative learning models. The subjects of the study were thirty-two student teachers enrolled in a master's degree program.

The results revealed that there was a statistically significant difference between prospective teachers' scores on learning experience measured across the three experimental conditions. The results also revealed that there was a statistically significant difference in achievement scores favoring both cooperative learning conditions. It was also reported that cooperative learning enhances perspective teachers' academic achievement as compared to traditional instruction. Further, it was reported that cooperative learning promoted an enriched, enjoyable and interactive learning experience. In addition to achievement, this study also provided evidence on the effect of learner centered approaches in the form of cooperative learning models on quality learning which is a focus of the study cited below. 
Atara, et al. (2000) examined the effectiveness of active learning through the use of several learning activities implemented in two undergraduate programs at the Hong Kong Polytechnic University. The effectiveness of these activities was investigated using questionnaires and interviews to explore students' attitudes and approaches to learning. Results showed that the activities used helped provoke the development of independent learning skills and the ability to apply knowledge. They also affected the quality of student learning by shaping the way the students studied and meeting the desired learning outcomes.

Another study showed the positive effects of learner centered approaches on the quality of learning. Video documentaries were used to ask students to explore problems associated with farmers (Gravoso and Pasa 2008). The students' learning outcomes and experiences were compared to a group of students who studied the same topics in a teacher-centered learning environment. The level of understanding of the problems by the student-centered groups was found to be consistently higher than that of the teacher-centered groups. The results also showed that the learner-centered environment tended to engage students in knowledge construction, while the teacher-centered environment fostered the mere absorption of information. It was concluded that technology can change and improve the quality of learning outcomes if designed to support knowledge construction in a learner-centered environment.

From the above studies, there is some evidence of the usefulness of learner- centered approaches in student learning. However, there are other studies that reveal the complex side of implementing these approaches. Baeten, Kyndt, Struyven, and Dochy (2008) focused on the relationships between experiences with portfolio assessment, students' approaches to learning and their assessment preferences. The method used for data collection was a pre- and post-test design in an authentic class setting using a questionnaire and an inventory to measure approaches to learning and assessment preferences inventory. The participants were 138 first-year undergraduate students who were assessed by means of portfolio assessment in a course that combined constructivist design principles and lectures.

The main results of the study were:

(a) students' preferences for student participation in examination and for permanent evaluation decreased significantly, (b) deep approaches were not enhanced, and (c) surface learning increased significantly; even though, the surface approach proved to be a significant negative predictor of the portfolio assessment score.

O'Sullivan (2003) conducted a case study, which explored the impact of learner-centered approaches on 145 unqualified primary teachers in Namibia where a learner-centered curriculum was introduced after its independence in 1990. The results of the study recommended that such an approach not be implemented. The researcher cited teacher professional capacity at the time of the study, limited resources, cultural factors and learner backgrounds as justification for this stance. Further, this study clarified some crucial issues. The researcher proposed the effectiveness of developing teachers' skills in the use of approaches, methods and skills which will bring about a great deal of learning. The study recommends considering the realities within which teachers work and experiment with strategies that seek to achieve student learning within the limitations of these realities.. 
Gijbels (2009) found out that students in a constructivist learning environment change their learning approaches towards a deeper approach and brought to light the effect that additional feedback had on the changes in learning approaches. Results showed that a deep approach is difficult to incite (see also Marton and Säljo 1997). The results also indicated that small changes in a learning environment do not necessarily lead to changes in students' approaches to their learning. The researcher provides an explanation based on the learning environment in which students might have perceived only the acquisition of facts and concepts as the learning process . Moreover, the assignments were considered solely an application of what was learned, and not a part of the learning process itself, which is similar to not perceiving an exam as part of the learning process.

Consequently, students might have reported only a part of their actual learning process. In addition, students' concepts of learning are difficult to change. Therefore, a seven-week course might not have been adequate in length. Furthermore, as the researcher points out that the instruments used in this research are best suited to investigating students' approaches to learning in "a traditional learning environment." As an example, the collaborative aspects of learning which were prominent in the learning environment used in this study form an essential part of these "new" learning environments. However, it is not certain that the instrument was capable of accurately grasping students' learning approaches in these environments. The researcher concludes by stating that "One cannot expect that the implementation of innovations will automatically result in positive changes. One has to be wary of how one implements new measures, how different innovations affect each other and how students perceive these measures" p (150)." It also requires the use of adequate instruments and adequate research methodology such as mixed-method research (Gijbels 2009).

Gijbels (2009)- in the study above- provides crucial factors that researchers should consider when trying to implement and evaluate student centered approaches. This study and the others presented here show that there are different factors that determine the positive or negative effects of these approaches. Some of these factors are: learners' perceptions and attitudes and their characteristics, length of time needed, the appropriate instruments used, how student centered approaches are implemented, teacher professional capacity, available resources, cultural factors and learner background.

\section{Context of the Study}

In an attempt to improve students' English language performance in Oman, the ministry of education embarked on a pilot project that converted 20 basic education schools into learner centered schools. The project was implemented in 2003 with funding and technical support from the US government's Middle East Partnership Initiative (MEPI). Amendments to the curriculum, change in classroom environment and professional development of teachers were done to suit the learner centered philosophy. Preliminary evaluations conducted in 2006 indicated positive results. In turn, the experiment was expanded to cover more schools in the Sultanate. 
In 2008 the Sultan Qaboos University teacher education program wanted to ensure that its graduates possessed necessary learner centered pedagogical skills to enable them to teach in learner centered environments. Methods courses which used traditional approaches were converted into learner centered courses and student teachers were invited to participate in sections where students were exposed to learner- centered classroom practices. This study intends to measure the impact of the learner-centered training of student teachers on learner performance in English language compared to the learner performance of those taught by student teachers with no exposure to learner centered pedagogy.

\section{Purpose}

The study aimed at examining the effect of learner-centered pre-service training on Basic Education learners' language performance. It investigated the difference in English language performance between learner- centered (experimental group) and non-learner- centered school students (control group). It also examined if differences existed between the experimental group and control group that could be attributed to gender and the school environment. Moreover, the study examined the experimental group's attitudes towards learning English.

\section{Questions}

The study attempted to answer the following questions:

1. Are there significant differences in English language performance between learner centered basic education school students and non-learner-centered basic education school students?

2. Is there a significant interaction effect on students' English language performance due to the type of school and students' gender?

3. Are there any significant differences in English language performance among learnercentered basic education school students which can be attributed to gender?

4. Are there any significant differences in English language performance among learner -centered basic education school students which can be attributed to the school environment?

5. How do all learner-centered and non-learner centered students in basic education schools perform in English language compared to the minimum required level of performance set by the Ministry of Education?

6. What is the learner centered basic education school students' attitudes towards learning English? 


\section{1) Macrothink}

\section{Method}

\subsection{Sample}

Two learner centered schools and two non-learner centered schools were involved in this study. Student teachers who were involved in the learner centered training were placed in learner centered schools for their clinical work. Those who were not in the learner centered training were placed in one of the schools that were not part of the Ministry of Education learner centered project. A standardized English language test and an attitude survey were used for data collection. The total sample of school students tested was 189 of whom 114 were from leaner centered schools (4 classes) and 75 from the non-learner centered schools (3 classes).

\subsection{Research Design}

This is a quasi-experimental study using pre-post control group design to test the effect of learner centered methodology on students' English language performance and attitudes. In this quasi-experimental study, the control group received conventional instruction whereas the experimental group was exposed to learner centered instruction.

\subsection{Research Tools}

The instruments used in this study are the National test designed by the Ministry of Education which was confidential and an attitude questionnaire that was adapted from the Ministry of Education learner centered methodology program document. The questionnaire was translated in order to be used by grade 5 learners. The Arabic and the English versions of the questionnaire were checked for validity by area specialists and practitioners.

\section{Results}

Table 1. Mean of the students' scores in Different language Skills by Student in Learner centered Group and Non-learner Centered Group

\begin{tabular}{llll}
\hline Skill & Gender & Learner-centered students & Non-learner-centered students \\
\hline \multirow{2}{*}{ Speaking } & Male & 35.19 & 25.34 \\
& Female & 36.04 & 30.26 \\
\multirow{4}{*}{ Writing } & Total & 35.64 & 27.83 \\
& Male & 50.67 & 38.94 \\
& Female & 56.06 & 52.27 \\
\multirow{3}{*}{ Reading } & Total & 53.51 & 45.70 \\
& Male & 42.78 & 38.78 \\
& Female & 51.92 & 46.05 \\
& Total & 47.59 & 42.47 \\
& Male & 42.88 & 34.36 \\
& Female & 48.01 & 42.87 \\
& Total & 45.58 & 38.67 \\
\hline
\end{tabular}


Generally, table (1) shows that females outperformed their males counterparts in all language skills (speaking, $X=36$, writing, $X=56$, and reading, $X=52$ ). The next table (table 2) shows the significant differences between the relative groups.

Table 2. MANOVA of EFL students Language Performance

\begin{tabular}{lllllll}
\hline $\begin{array}{l}\text { Dependent } \\
\text { variable }\end{array}$ & Source of variation & $\begin{array}{l}\text { Sum of } \\
\text { Squares }\end{array}$ & $\begin{array}{l}\text { Dean } \\
\text { Square }\end{array}$ & F & Sig. \\
\hline Speaking & School Type & 2758.081 & 1 & 2758.081 & 13.804 & .000 \\
& Gender & 377.612 & 1 & 377.612 & 1.890 & .171 \\
& School Type * gender & 187.008 & 1 & 187.008 & .936 & .335 \\
Writing & School Type & 2720.064 & 1 & 2720.064 & 6.030 & .015 \\
& Gender & 3957.000 & 1 & 3957.000 & 8.773 & .003 \\
& School Type * gender & 712.496 & 1 & 712.496 & 1.580 & .210 \\
Reading & School Type & 1097.740 & 1 & 1097.740 & 2.389 & .124 \\
& Gender & 3041.002 & 1 & 3041.002 & 6.617 & .011 \\
& School Type * gender & 39.502 & 1 & 39.502 & .086 & .770 \\
Total & School Type & 2109.538 & 1 & 2109.538 & 9.649 & .002 \\
& Gender & 2099.701 & 1 & 2099.701 & 9.604 & .002 \\
& School Type * gender & 129.181 & 1 & 129.181 & .591 & .443 \\
\hline
\end{tabular}

Table 2 above shows that the type of schooling is not affected by gender. There are no interaction effects between the type of school and gender on student performance in all language skills at the level of 0.05 (speaking $\mathrm{p}=0.33$, writing $\mathrm{P}=0.21$, reading $=0.77$, total 0.444) However, the school type variable is significant in speaking, writing as well as the total $(\mathrm{P}=0.00, \mathrm{P}=0.015, \mathrm{P}=0.002)$, respectively. Further, gender is significant in writing and reading with totals of $(\mathrm{P}=0.003, \mathrm{P}=0.01$ and $\mathrm{P}=0.02)$ in favor of females. However, learner centered students' mean scores are slightly higher than their counterparts in non-learner centered schools.

Table 3. T-tests for Gender Differences in Leaner-centered Schools according to language skills

\begin{tabular}{lllcccc}
\hline \multirow{2}{*}{ Speaking } & Gender & $\mathrm{N}$ & Mean & Std. Deviation & $\mathrm{T}$ & Sig. (2-tailed) \\
& Male & 54 & 35.1852 & 15.93658 & -.302 & .764 \\
\multirow{3}{*}{ Writing } & female & 60 & 36.0417 & 14.38935 & & \\
& Male & 54 & 50.6734 & 26.61305 & -1.199 & .233 \\
\multirow{4}{*}{ Reading } & Female & 60 & 56.0606 & 21.26525 & & \\
& Male & 54 & 42.7778 & 22.62631 & -2.241 & .027 \\
& Female & 60 & 51.9167 & 20.91329 & & \\
& Male & 54 & 42.8788 & 16.73494 & -1.720 & .088 \\
& Female & 60 & 48.0049 & 15.08248 & & \\
\hline
\end{tabular}

Table 3 above shows there is a significant difference in the performance among students in the learner-centered school in reading only at the 0.05 level $(\mathrm{P}=0.0 .27)$ in favor of females. However, there are no significant differences between males and females mean scores in 
general proficiency, speaking and writing at 0.05 level. However, despite the significant difference, it can be clearly observed that female EFL learners outperformed male EFL learners. The findings also reveal that, in general, when EFL learners are grouped according to gender, neither female nor male EFL learners obtained a score of fifty percent or more. However, female EFL learners scored slightly over fifty percent in writing and reading ( $\mathrm{X}=56.06$ and $\mathrm{X}=51.91$ respectively). Males, on the other hand, obtained slightly above fifty percent in reading only $(\mathrm{X}=50.67)$

Table 4. T-tests of Learner-Centered school students' differences with regard to school environment

\begin{tabular}{llccccc}
\hline \multirow{2}{*}{ Speaking } & School & $\mathrm{N}$ & Mean & $\begin{array}{c}\text { Std. } \\
\text { Deviation }\end{array}$ & $\mathrm{T}$ & Sig. (2-tailed) \\
& Wahah & 57 & 33.5526 & 12.31060 & -1.650 & .102 \\
& Nobough & 56 & 38.1696 & 17.09260 & & .000 \\
\multirow{2}{*}{ Readiting } & Wahah & 57 & 42.6635 & 24.56460 & -5.447 & .316 \\
& Nobough & 56 & 64.6916 & 17.82693 & & \\
\multirow{2}{*}{ Total } & Wahah & 57 & 49.8246 & 19.77473 & 1.007 & .012 \\
& Nobough & 56 & 45.6250 & 24.34716 & & \\
\hline
\end{tabular}

Table 4 shows significant differences in EFL learners' language performance between Learner-centered basic education learners due to the school (place) in favor of Alnobough school at the 0.05 level of significance $(\mathrm{P}=0.012)$ with means of 49.50 for Alnobough and 42.01 for Alwahah. What contributed to this general significant difference between the schools is the learners scores in writing. That is, the results show significant differences in students' performance in speaking with Alnobough at the level of 0.001 and a mean of 64.70 for Alnobough while the Alwahah school had a mean of only 42.66. It is also worth noting that learners in Nobough school had a mean of just below fifty percent ( $X=49.495)$.

Table 5. One-sample t-test results for total group means on different skills compared to the Minimum required level

\begin{tabular}{lllll}
\hline & $\mathrm{N}$ & Mean & Std. Deviation & Sig. (2-tailed) \\
\hline Speaking & 189 & 32.5397 & 14.62173 & .000 \\
Writing & 189 & 50.4089 & 21.92358 & .798 \\
Reading & 189 & 45.5556 & 21.82701 & .006 \\
Total & 189 & 42.8342 & 15.42161 & .000 \\
\hline
\end{tabular}

Table 5 shows that, overall, there is a significant difference between the total means of the students' language performance in different skills and the minimum required level (i.e. score) at the 0.01 level with a mean $(\mathrm{X}=42.8342 \mathrm{P}=0.001)$. With regard to the specific language skills, the results reveal that there are significant differences between the means of students performance in speaking and reading at the 0.01 compared to the minimum required level with means ( $\mathrm{X}=32.5397$ and $45.555, \mathrm{P}=0.001$ and 0.006 respectively). However, there is no 
significant difference in students' performance in writing and the minimum level of performance.

Generally, the findings indicate that the students' performance did reach the minimum required level with various degrees of level and significance. The findings also reveal that the students performed better in writing than in reading or speaking. Speaking skill obtained the lowest mean of the three language skills being examined. This is probably because of the insufficient focus on speaking inside the classroom and no formal instruction in speaking in addition to lack of exposure for students to practice speaking outside the classroom.

Table 6. One-sample t-test results for comparing differences between means of Non-learner centered Basic Education students in English Language compared to the minimum required level

\begin{tabular}{lcccc}
\hline \multicolumn{1}{c}{ Skill } & Sample & Mean & SD & Sig. \\
\hline Speaking & 75 & 27.8333 & 12.59647 & 0 \\
Writing & 75 & 45.697 & 17.45944 & 0.036 \\
Reading & 75 & 42.4667 & 21.13939 & 0.003 \\
Total & 75 & 38.6657 & 13.52642 & 0 \\
\hline
\end{tabular}

Minimum required score $=50$

With regard to the non-learner centered students, table 6 shows that there are significant differences between the means of the students' overall language performance and of the individual skill separately (speaking, writing, reading) and the minimum required level at the 0.01 level with the means(X=total 38.6657, speaking 27.8333, writing 45.6970, reading 42.4667, $\mathrm{P}=0.01)$. Generally, the findings indicate that the students' performance in general English and in the three skills was lower than the minimum required level prescribed by the Ministry of Education.

Table 7. One-sample t-test results for comparing differences between means of learner centered Basic Education students in English Language compared to the Minimum required level

\begin{tabular}{lcrrc}
\hline Skill & $\mathrm{N}$ & Mean & SD & Sig. (2-tailed) \\
\hline Speaking & 114 & 35.636 & 15.0802 & 0 \\
Writing & 114 & 53.5088 & 23.9917 & 0.121 \\
Reading & 114 & 47.5877 & 22.1243 & 0.247 \\
Total & 114 & 45.5767 & 16.023 & 0.004 \\
\hline
\end{tabular}

As for the learner centered students, table 7 shows that there are significant differences between the means of the students' overall language performance and of the speaking skill separately and the minimum required level at the 0.01 level in favor of the minimum required level with the means ( $\mathrm{X}=$ total 45.5767, speaking $35.6360 \mathrm{P}=0.01$ ). However, there were no significant differences in means of students' language performance in the skills of writing and reading and the minimum required level.

Generally, the findings revealed that that the students' overall language performance and 
speaking ability were significantly lower than the minimum required level prescribed by the Ministry of Education. In the case of reading, the students performed lower than the minimum required level but was not significant. Student mean scores in writing, however, were higher, but were not significant compared to the minimum required level.

In General, the findings indicate that neither type of instruction (i.e. learner-centered nor non-learner centered) resulted in improved students' scores as measured by the Ministry of Education proficiency tests. All skills but one of those included in the study fell below the minimum required level prescribed by the MOE. This shows no remarkable gains in students' language improvement as a result of the teachers' exposure or non-exposure to learner centered methodologies. However, students' attitudes towards the learner centered approach seem to be telling a different story.

Table 8. Learner centered basic education school students' attitudes towards learning English $(n=114)$

\begin{tabular}{|c|c|c|c|}
\hline Q. No. & Question & Mean & SD \\
\hline 19 & Did you benefit from the learning resource centers? & 96 & .185 \\
\hline 1 & Did you enjoy learning English in school? & 96 & .206 \\
\hline 16 & Do you like the learning resource centers? & 93 & .257 \\
\hline 17 & Do you like the learning center activities? & 92 & .271 \\
\hline 5 & Did you learn how to read? & 89 & .308 \\
\hline 9 & Does your teacher ask you questions? & 89 & .319 \\
\hline 20 & Do you benefit from learning center activities in the classroom? & 89 & .319 \\
\hline 3 & Do you find the English school books and materials interesting? & 89 & .394 \\
\hline 18 & $\begin{array}{l}\text { Do you benefit from the information and programs presented in the morning } \\
\text { meetings? }\end{array}$ & 88 & .330 \\
\hline 2 & Do you like the classroom activities? & 88 & .330 \\
\hline 15 & Do you like the information and programs presented in the morning meetings? & 87 & .340 \\
\hline 6 & Do you like reading? & 87 & .340 \\
\hline 12 & $\begin{array}{l}\text { Does your mother or father help you when you need/do not understand } \\
\text { something? }\end{array}$ & .85 & .358 \\
\hline 10 & Does your teacher allow you to ask questions in class? & 85 & .358 \\
\hline 13 & Do you have any role in the classroom? Do you have a job in the classroom? & 83 & .397 \\
\hline 11 & Do your classmates help you when you need/do not understand? & 83 & .374 \\
\hline 14 & Does your mother or father come to school to ask about you? & 78 & .416 \\
\hline 4 & Do you sometimes take your books and materials home? & 75 & .432 \\
\hline 8 & Do you have anything / any work on the classroom wall? & 52 & .502 \\
\hline 7 & Did you write a story? & 35 & .479 \\
\hline Overall & & $\begin{array}{l}82.9375 \\
(3.3175)\end{array}$ & .46682 \\
\hline
\end{tabular}

It is clearly observed from the results in table 8 that students have generally high positive attitudes towards learner centered approach. The means of sixteen out of twenty items are above 80 . The means of the remaining four items range between 78 and 35. Only one item 
obtained a mean of less than $50(\mathrm{X}=35)$. The reason could be that grade 4 students are not exposed to writing stories at this level.

Though not reaching high levels of performance, these findings suggest that learner centered methodology does not only lead to significantly better performance than students taught by teachers who were not exposed to learner centered methodology but it also develops positive attitudes towards the learner centered approach and English language learning in general.

\section{Summary of Results and Conclusions}

The following is a summary of the main findings and conclusions:

- Significant differences were found between the performance of students in learner centered schools compared to those in schools using non learner centered approach, in favor of the learner centered schools.

- Significant differences were found within the learner centered schools which can be attributed to the school environment.

- No significant differences were found that could be attributed to gender.

- Weak language performance was seen in both learner centered and non-learner centered groups.

- The attitude questionnaire administered to learner centered students indicated they had positive attitude towards learning English.

The current study shows some evidence that supports the use of learner centered methodology which is similar to various previous studies (Atara et al 200; Geisli, 2009; and Ahmed and Mahmood, 2010) that revealed positive effects of student-centered approaches on students' achievement. However, the current study did not reveal significant differences between the two groups (control and experimental) in students' language improvement in all language skills. It is, therefore, still not that clear how much this methodology can contribute to learners' language improvement in general. This is supported by studies that showed the complex side of implementing this methodology (Gijbels, 2009; Baeten at el, 2008, and O’Sullivan, 2003).

In order to see the actual effect of the learner-centered approach on pre-service teacher education project, concrete evidence from students' school performance is necessary. This is the only way that clearer and more solid evidence can be collected to show the success of the approach. This study went beyond looking into the effect of the project on the student teacher. Rather, it looked at the multiple effects of the learner-centered methodology on the school students' language performance as compared with another traditional instructional approach commonly used in Oman. Teachers and curriculum developers will benefit from the findings of this study in improving teaching and curriculum development in Oman. 


\section{References}

Ahmed, Z., \& Mahmood, N. (2010). Effects of Cooperative Learning vs. Traditional Instruction on Prospective Teachers' LearningExperience and Achievement. Ankara University. Journal of Faculty of Educational Sciences, 43(1), 151-164.

Atara, S. Wong Leung, R. Woon, Ch., \& David, K. (2000). An Implementation of Active Learning and its Effect on the Quality of Student Learning. Innovations in Education $\begin{array}{llll}\text { and } \quad \text { Teaching 381-389. } & \text { 37), }\end{array}$ http://dx.doi.org/10.1080/135580000750052991

Baeton, M., Kyndt, E. Struyven, K., \& Dochy, F. (2010). Using Student-Centered learning environment to stimulate deep approaches to learning: Factors encouraging or discouraging their effectiveness. Educational Research Review, 5(3), 243-260. http://dx.doi.org/10.1016/j.edurev.2010.06.001

Burnard, P. (1999). Carl Rogers and postmodernism: Challenged in nursing and health sciences. Nursing and Health Sciences, 1, 241-247. http://dx.doi.org/10.1046/j.1442-2018.1999.00031.x

Carlile, O. \& Jordan, A. (2005). It works in practice but will it work in theory? The theoretical underpinnings of pedagogy. In O'Neill, G. Moore. S, \& McMullin, B. (eds), Emerging Issues in the Practice of University Learning and Teaching. Dublin: AISHE.

Cobb, P. (1999). Where is the Mind? In P. Murphy (Ed.). Learners, Learning and Assessment. London: Open University Press.

Gravoso, R.S., \& Pasa, A. E. (2008). Design and Use of Instructional Materials for Student-Centered Learning: A Case in Learning Ecological Concepts. The Asia-Pacific Education Researcher, 17(1), 109-120. http://dx.doi.org/10.3860/taper.v17i1.353

Geisli, Y. (2009). The effect of student centered instructional approaches on student Success. Procedia Social and Behavioral Sciences 1 (2009) 469-473 World Conference on $\begin{array}{llll}\text { Educational } & \text { Sciences } & \text { Retrieved } & \text { from }\end{array}$ www.journals.elsevier.com/procedia-social-and-behavioral-sciences

O'Neill, G., \& McMahon, T. (2005). Student-centred learning: what does it mean for students and lecturers? In O'Neill, G. Moore, S. \& McMullin, B. (eds). Emerging Issues in the Practice of University Learning and Teaching. Dublin: AISHE, pp. 27-36. http://dx.doi.org/10.1016/S0738-0593(03)00018-X

O’Sullivan, M. (2004). The reconceptualisation of learner-centred approaches: a Namibian case study. International Journal of Educational Development, 24, 585-602

Marton, F., \& Saljo, R. (1997). Approaches to learning. In F.Marton, D. Hounsell \& Entwistle, $\mathrm{N}$. (eds), The experience of learning. Implications for teaching and studying in higher education. Edinburgh: Scottish Academic Press.

Richards, J. C. (2002). 30 Years of TEFL/TESL: A Personal Reflection. RELC Journal, 33(1), 
1-35. http://dx.doi.org/10.1177/003368820203300201

Rogers, C. R. (1983). As a teacher, can I be myself? In Freedom to Learn for the 80's. Ohio: Charles E. Merrill Publishing Company.

Simon, B. (1999). Why no pedagogy in England? In Leach, J. \& Moon, B. (eds), Learners and Pedagogy. London: Sage Publications.

Schuh, K. L. (2004). Learner-centered principles in teacher-centered practices? Teaching and Teacher Education, 20, 833-846. http://dx.doi.org/10.1016/j.tate.2004.09.008

Taylor, P. G. (2000). Changing Expectations: Preparing Students for Flexible Learning. The International Journal of Academic Development, 5(2), 107-115. http://dx.doi.org/10.1080/13601440050200716

Trigwell, K. et al. (1999). Relations between teachers' approaches to teaching and students' approaches to learning. Higher Education, 37, 57-70. http://dx.doi.org/10.1023/A:1003548313194

Young, J. (2000). Comment: Who needs Analysis? ELT Journal, 54(1), 72-74. http://dx.doi.org/10.1093/elt/54.1.72

\section{Copyright Disclaimer}

Copyright for this article is retained by the author(s), with first publication rights granted to the journal.

This is an open-access article distributed under the terms and conditions of the Creative Commons Attribution license (http://creativecommons.org/licenses/by/3.0/). 